\title{
Regeneration of Pancreatic Insulin-Producing Cells By In Situ Adaptive Cell Conversion
}

\author{
Simona Chera ${ }^{1}$ and Pedro L. Herrera ${ }^{2}$
}

(1) Department of Clinical Science, Faculty of Medicine and Dentistry, University of Bergen, Jonas Lies vei 65, 5021 Bergen, Norway

(2) Department of Genetic Medicine \& Development, Faculty of Medicine, Institute of Genetics and Genomics in Geneva (iGE3), and Centre facultaire du diabète, University of Geneva, 1 rue Michel-Servet, 1211 Geneva-4, Switzerland

Running title: Islet Cell Conversion

Total word number: 2882

Number of figures and tables: 4 


\begin{abstract}
The impaired ability to produce or respond to insulin, a hormone synthetized by the pancreatic $\beta$-cells, leads to diabetes. There is an excruciating need of finding new approaches to protect or restore these cells once they are lost. Replacement and ex vivo directed reprogramming methods have an undeniable therapeutic potential, yet they exhibit crucial flaws. The in vivo conversion of adult cells to functional insulin-producing cells is a promising alternative for regenerative treatments in diabetes. The stunning natural transdifferentiation potential of the adult endocrine pancreas was recently uncovered. Modulating molecular targets involved in $\beta$-cell fate maintenance or in general differentiation mechanisms can further potentiate this intrinsic cell plasticity, which leads to insulin production reconstitution.
\end{abstract}




\section{Introduction}

Diabetes, i.e. the excessive production of urine (polyuria) associated with tenacious thirst (polydipsia), is a symptom common to many different diseases characterized by a debilitating persistent excess of glucose in circulating blood (hyperglycemia). The high blood sugar is typical of diabetes mellitus (distinct from diabetes insipidus, a "brain-kidney" disease). Diabetes mellitus results from the impaired ability of either (i) the endocrine pancreas to produce the hormone insulin, or (ii) the target tissues (brain, liver, muscle...) to respond to it, or both. The two prevailing forms of diabetes, named Type 1 and Type 2 (T1D and T2D), are characterized by the loss of insulin-producing islet cells: total or near total in T1D, due to an autoimmune destruction, or variable and partial in $\mathrm{T} 2 \mathrm{D}^{1,2}$. A cure for insulin-dependent diabetes requires the reconstitution of a functional $\beta$-cell mass, either through in situ regeneration or by cell-based replacement therapies, i.e. the transplantation of surrogate $\beta$-like cells obtained from stem cells ${ }^{3,4}$ (Figure 1).

In recent years, several observations have revealed an astonishing intrinsic plasticity in the pancreatic islets of Langerhans ${ }^{5}$. These findings allow envisioning new strategies for treating diabetes by exploiting the in vivo transdifferentiation potential of diverse pancreatic cell types (Figure 1). Due to space constrains, in this mini-review we will solely address the main advances towards this goal by focusing exclusively on the experimental settings in which reprogramming into insulin production (either natural or guided, of pancreatic or extrapancreatic cells) satisfied the following criteria: i) was described in vivo, ii) occurred during postnatal life, and iii) reinstated, transiently or permanently, blood sugar levels (glycemia) in diabetic animals.

\section{Choosing a $\beta$-cell reconstitution strategy: replacement vs. regeneration}

The last 20 years have seen a rapid development of $\beta$-cell replacement strategies, the most common being the allotransplantation of healthy pancreatic islets from cadaveric donors ${ }^{6}$ (Figure 1). This method is limited by the scarcity of donors and the inherent graft decay, with only $44 \%$ of the recipients being insulin-independent 3 years after transplantation ${ }^{7}$. Consequently, finding a more accessible source of $\beta$-cells is mandatory for the development of regenerative therapies to treat diabetes.

An increasingly popular line of research focuses on generating mature insulin-producing cells in vitro starting from human induced pluripotent stem cells (hiPSC), derived from somatic cells of normal donors (such as fibroblasts), as an alternative to islet allotransplantation (Figure 1). Although this approach has the advantage of generating a potentially unlimited number of $\beta$-like cells, it still faces some controversy regarding graft rejection complications $^{8,9}$, thus requiring further research directed at designing optimal delivery 
methods (encapsulation devices) ${ }^{10}$, or developing genetically-modified $\beta$-like cells from autologous patient-derived iPSC ${ }^{11}$. Also, most current cell differentiation protocols have limiting flaws linked to heterogeneous yields and tumorigenesis ${ }^{3,12,13}$.

An alternative approach to the in vitro/ex vivo differentiation of surrogate $\beta$-cells is the exploitation of the natural in vivo $\beta$-cell regenerative capacity of the pancreas, primarily by stimulating $\beta$-cell self-replication ${ }^{14-16}$ (Figure 1). Nevertheless, this approach is inadequate for treating patients with complete or near-complete absence of $\beta$-cells, as reported in many T1D cases, among other limitations.

\section{Adaptive transdifferentiation is a conserved regeneration mechanism}

The body has developed two main natural strategies to replenish lost cell populations, which are different depending upon the capacity of the cells to enter the cell cycle (summarized in Figure 2).

Cell transdifferentiation, conversion, reprogramming or fate change, is a stable switch in cell identity, where a terminally differentiated cell converts into a different mature cell-type, with or without experiencing a transitional proliferative stage (reviewed in ${ }^{17-22}$ ). It occurs naturally in response to various stressors (reviewed $\mathrm{in}^{23}$ ) and represents an ancient and widespread regenerative strategy among metazoans, being described from cnidarians to vertebrates (reviewed in ${ }^{19,24-26}$; Table 1). However, the transdifferentiation nature of the regenerative process remains controversial in some cases, because it may occur alongside other regenerative mechanisms ${ }^{22,27,28}$. Two examples are fin regeneration in fish and limb regeneration in amphibians, where cell lineage tracing experiments have revealed that most cell types are lineage-restricted ${ }^{29}$ : upon injury, differentiated cells in the proximity of the wound form the blastema, i.e. they de-differentiate before rebuilding the original tissue by giving rise to the original cell type without a change in fate $\mathrm{e}^{30-32}$. Interestingly though, fin regeneration still occurs after osteoblast ablation, thus proving that bone can regenerate from alternative sources ${ }^{33}$.

Two different mechanisms of cell transdifferentiation were described already a century ago: (1) direct conversion, whereby cell type A trans-fates directly into cell type B, in absence of cell division and displaying a transient hybrid phenotype, and (2) indirect conversion, where cell type A de-differentiates, proliferates and re-differentiates acquiring the B cell type fate. The first process is characteristic for morphallaxis, while the second is a type of epimorphosis ${ }^{34}$ (Figure 2).

In order to determine the occurrence of a cell fate conversion event in response to injury, the resulting differentiated cell type must be i) lineage-traced to its original progenitor, and ii) characterized at the morphological and molecular levels ${ }^{35}$. These changes can be reflected by 
wide differences in the transcriptional landscape, including, for instance, the expression of specific genes such as those encoding peptidic hormones and the enzymes involved in their conversion and secretion ${ }^{21}$.

Cells and their progeny can be irreversibly (genetically) tagged in vivo, in transgenic animals ${ }^{36,37}$ (reviewed $\mathrm{in}^{38-40}$ ). The first in vivo cell lineage tracing analysis during mouse embryonic development using the Cre/loxP system was performed by one of us in a study of pancreatic cell fate allocation ${ }^{41}$. A few examples of in vivo lineage-tracing studies in development and regeneration in other organs are indicated here ${ }^{5,42-47}$. This cell labeling method eliminates any ambiguity regarding the identity of the precursors of converted cells ${ }^{48-}$ ${ }^{50}$. Moreover, the same transgenic setup may be used for the simultaneous constitutive or inducible, transient or irreversible, modulation of key genes in the cell type of interest.

The lack of a cell tracing system is a major limitation in any study involving human diabetic patients ${ }^{51}$. It is also a limiting factor in analyses of experimental diabetes: for instance, in a murine model of severe injury in which pancreatic duct ligation was combined with alloxaninduced $\beta$-cell destruction, the authors claimed that $\alpha$-cells convert into $\beta$-like cells based only on marker co-expression, which is never conclusive ${ }^{52}$.

\section{Guided pancreatic cell transdifferentiation: the artificially induced cell plasticity}

In homeostatic conditions, $\beta$-cells are located in endocrine units termed islets of Langerhans, intermingled between the acini and ducts of the exocrine pancreas. Besides the preponderant $\beta$-cells, pancreatic islets contain other endocrine cell types, each secreting a different hormone: glucagon ( $\alpha$-cells), somatostatin $(\delta$-cells) and pancreatic polypeptide (PP-cells).

The regenerative potential of the pancreas was first described almost 20 years ago, yet without adequate lineage tracing tools, when several studies reported the emergence of new endocrine cells, including insulin-producing cells, following tissue injury (reviewed in $^{26}$ ). The authors suggested an exocrine cell transdifferentiation process, rather than the recruitment of "dormant" stem cells.

Recent years have witnessed attempts at generating insulin-producing cells in vivo by ectopically inducing $\beta$-cell-specific programs in extra-pancreatic and pancreatic cells, either by gene therapy or pharmacologically. The objective of any guided cell-fate switching strategy is to asymptotically reach a "perfect" conversion while minimally interfering with the original target cell population, so as to avoid paradoxical side effects. One example is the study of Melton and colleagues ${ }^{53}$, who reprogrammed exocrine cells into insulin production in mice by injecting into the pancreas different combinations of adenoviruses encoding 9,6 or 3 key $\beta$-cell transcription factors; the highest conversion rate inversely correlated with adenoviral cocktail complexity. Only 3 key transcription factors were sufficient for $\beta$-cell 
conversion induction: Pdx1 (required during early pancreas development as well as for $\beta$-cell maintenance), Ngn3 (required for islet endocrine progenitor fate allocation) and MafA (required for $\beta$-cell maturation). In a long-term study, Zhou and colleagues reported the persistence of induced $\beta$-like cells for up to 13 months and, interestingly, their aggregation into islet-like structures ${ }^{54}$. These studies and others ${ }^{55}$ showed that these 3 factors are absolutely necessary for an efficient acinar-to- $\beta$-like transdifferentiation.

In another study ${ }^{56}$, Heimberg and colleagues reported that the acinar cell transdifferentiation can be pharmacologically induced with cytokines (epidermal growth factor and ciliary neurotrophic factor treatment). The regenerated $\beta$-like cells were able, like in the Zhou study, to rescue diabetes and maintain euglycemia for up to 8 months in mice where diabetes was induced by streptozotocin (STZ) administration.

The endocrine pancreas is a natural choice as source of new $\beta$-like cells. Due to the difference in ratio between non- $\beta$ - and $\beta$-cells in islets ( $\beta$-cells represent almost $80 \%$ of the islet cell mass in rodents), one concern of the in vivo islet cell conversion towards the $\beta$-cell fate is the risk of decreasing or even losing another islet cell type. In this regard, Collombat et al. reported that the transgenic misexpression of the $\beta$-cell-specific transcription factor Pax 4 in $\alpha$ cells (Pax4OE) leads to a loss of $77 \%$ of them, together with a progressive increase in insulin + cells $^{57}$. Indeed, most Pax4OE $\alpha$-cells became $\beta$-like cells. The authors hypothesized that the constant $\alpha$-to- $\beta$-cell conversion process depleted the $\alpha$-cell compartment, i.e. the pancreatic glucagon content, hence triggering a compensatory $\alpha$-cell neogenesis through the mobilization of ductal precursors. The newly formed $\alpha$-cells adopted a $\beta$-cell fate, generating a positive feedback loop, which ultimately resulted in islet hyperplasia ${ }^{49}$ (reviewed $^{58}$ ). Nevertheless, the authors' interpretation is refuted by the lack of any compensatory $\alpha$-cell neodifferentiation in a genetic model of almost complete $\alpha$-cell ablation ${ }^{59}$, thus raising the possibility that an alternative explanation accounts for the observed series of events. In fact, by using a genetic model allowing the specific and inducible ablation of $98 \%$ of adult $\alpha$-cells, we observed that the remaining $2 \% \quad \alpha$-cell mass maintains basal glucagon levels (glucagonemia) ${ }^{59}$. This is incidentally encouraging, since an induced massive $\alpha$-cell conversion could be envisioned in guided $\alpha$-cell conversion protocols (see below).

The important concept, however, is that the ectopic expression of just one single $\beta$-cellspecific transcription factor in $\alpha$-cells is sufficient to steadily transdifferentiate them towards a stable $\beta$-cell phenotype. Moreover, the Pax4OE-induced $\beta$-like converted $\alpha$-cells were able to restore the glycemic control in mice made diabetic with STZ ${ }^{57}$.

\section{Extra-pancreatic tissues: a new source for guided $\beta$-cell generation}

Likely, the number and type of factors required for acquiring a $\beta$-like cell phenotype vary depending on the targeted source cell type. Most transdifferentiation studies concern the 
pancreas, but there is also interest in organs with a related developmental origin, such as the liver $^{60,61}$ and gut ${ }^{62}$.

In one such study, Slack and colleagues were able to generate glucose sensing insulinsecreting cells in diabetic mice by converting Sox9+ cells, which are located in the small bile ducts of the liver ${ }^{63}$. Interestingly, transdifferentiation was induced by a single polycistronic adenovirus encoding the same 3 factors Pdx1, Ngn3 and MafA, indicating that this trio is also highly efficient at inducing a $\beta$-like cell fate in extra-pancreatic tissues.

Overexpression of $\beta$-cell-specific factors is not the only alternative for making $\beta$-like cells. For instance, although the transcription factor FoxO1 is expressed in $\beta$-cells, it is not a $\beta$-cellspecific marker, and its inactivation does affect neither the formation nor the cell architecture of the endocrine pancreas. By inactivating FoxO1 in gut Ngn3+ enteroendocrine precursor cells of mice ${ }^{64}$, Accili and co-workers directed their differentiation towards a $\beta$-cell fate. The resulting cells expressed $\beta$-cell maturity markers and were able to cure diabetes.

This group also showed that, intriguingly, the constitutive selective inactivation of FoxO1 in $\beta$-cells leads to their de-differentiation in situations of metabolic stress ${ }^{65}$. This observation has led the authors to postulate that, instead of dying, perhaps some $\beta$-cells dedifferentiate in T2D.

\section{Spontaneous reprogramming of pancreatic islet non- $\beta$-cells: the innate plasticity}

To accurately determine if the adult pancreas can regenerate new $\beta$-cells once they are lost, like in T1D, and to characterize the cellular and molecular programs activated in the pancreas in response to $\beta$-cell loss, we used specific cell tracing tools in a transgenic model of inducible acute, rapid, selective and total $\beta$-cell remova $1^{48,50}$.

We found that, unexpectedly, $\beta$-cell ablation triggers the natural and spontaneous reprogramming of a small fraction $(\sim 2 \%)$ of the adult glucagon-producing $\alpha$-cells into insulin production. This $\alpha$-to- $\beta$ conversion includes an intermediary hybrid transitional stage of insulin+/glucagon + bihormonal cells, which was confirmed by genetic lineage tracing analyses $^{48}$. Of note, this is one of the very few reported cases of naturally occurring direct transdifferentiation in the animal kingdom, as it occurs in the absence of cell proliferation. Probably as a consequence of the proliferation-independent character of the change of identity process, $\alpha$-cells retain the capacity of engaging into insulin production in aged mice as well, demonstrating a persistence of plasticity throughout life, which could have clinically relevant implications ${ }^{50}$.

Further studies on the influence of age on $\beta$-cell reconstitution following total $\beta$-cell ablation revealed that juvenile prepubescent mice always recover from diabetes after near-total $\beta$-cell ablation ${ }^{50}$. Moreover, their recovery was faster, being able to regain a glycemic control by 5 months of regeneration, correlated with a rapid replenishment of the $\beta$-cell pool. Surprisingly, 
genetic lineage-tracing studies revealed a completely novel regeneration mechanism, involving the massive recruitment of another hormonal cell type, $\delta$-cells, which dedifferentiate to a progenitor stage, reenter the cell cycle, and recapitulate embryonic development to become insulin producers. Interestingly, this early timeline of the juvenile regeneration mechanism resembles closely the one described for lens regeneration in urodeles (reviewed $\mathrm{in}^{5,21,25}$ ). The $\delta$-to- $\beta$ reprogramming is confined to a very restrictive window at the beginning of regeneration and is required for generating a "minimal pool" of insulin producing $\beta$-like cells. These regenerated $\beta$-like cells secreted insulin and expressed typical $\beta$ cell-specific markers, yet they displayed striking differences in the expression of key cell cycle regulators. For this reason, these cells were able to undergo several rounds of proliferation and finally reconstituted up to $30-70 \%$ of the age-matched control $\beta$-cell mass. Notably, even after 2 years of regeneration the recovered $\beta$-cell mass never exceeded the one of age-matched controls suggesting a stringent regulation of the regeneration event, consistent with the observations in classical regenerative structures and systems.

The efficient juvenile regeneration mechanism raises the interest for developing "rejuvenation" strategies aimed at fostering or maintaining the juvenile regenerative mechanism later in life $\mathrm{e}^{50}$. In this respect, the initial, yet limited, comparative transcriptional analysis following total $\beta$-cell loss revealed that $\mathrm{FoxOl}$ and its downstream effectors display a divergent behaviour in juvenile and adult $\delta$-cells upon injury. FoxOl is a transcription factor involved in cell cycle and senescence regulation. Its decrease in juvenile $\delta$-cells and the detected low levels of its direct targets, such as senescence markers Cdkn1a (p21) and $C d k n 1 b$ (p15Ink4b), was consistent with an increased proliferative capacity. In contrast, following injury, FoxOl and cyclin-dependent kinase inhibitors were upregulated in adult $\delta$ cells, thus potentially explaining their incapacity to engage into an efficient regenerative program during adulthood. Interestingly, the juvenile mechanism could be somewhat mimicked with a pharmacological inhibition of FoxOl after injury, which promoted the $\delta$-to$\beta$ conversion in adulthood ${ }^{50}$.

\section{Prospective}

The production of experimental models for selective cell ablation in vivo will continue to lead to discoveries about tissue homeostasis and adaptive cell plasticity during embryonic development and during regeneration in pathological conditions or after injury, as has been the case in the pancreas ${ }^{48,66}$.

In vivo generation of surrogate $\beta$-cells from alternative non- $\beta$-cell sources represents a promising approach to treat diabetes, especially when $\beta$-cell loss is total. It appears that there 
may be efficient regeneration of $\beta$-cells in children with T1D or having undergone subtotal pancreatectomy ${ }^{5,67,68}$. Also, insulin+/glucagon+ bihormonal cells have been described in human diabetic patients ${ }^{69-71}$ and upon ex vivo epigenetic manipulation ${ }^{72}$, suggesting that human $\alpha$-cells might also display the plasticity allowing insulin production. Yet, whether these are reprogrammed $\alpha$-cells remains mysterious; since it is not possible to lineage-trace them to their origin, these could on the contrary be de-differentiated $\beta$-cells that start expressing glucagon, as claimed by some ${ }^{51}$.

The natural regeneration potential of the pancreas is age-dependent, with two distinct reprogramming mechanisms being employed according to the age at which the regenerative stressor occurs. The efficient juvenile regeneration is proliferation-dependent and hence restricted to a narrow window during early post-natal life. Current evidence suggests that unknown factors promote the accumulation of senescence markers in adult pancreatic islet cells, thus triggering a steep proliferation potential decrease and blocking the efficient juvenile regenerative program. These factors could be linked to sexual maturation, ageing, dietary change or other. In contrast, the adult regeneration mechanism is proliferationindependent and consequently the cell senescence status does not affect the 1:1 direct transdifferentiation event (age-independent). A consequence of these observations is that, besides cell sources and target molecules, one should also consider the age of a tissue when designing replacement strategies.

Understanding the cellular and molecular basis of innate adaptive islet plasticity and pancreas development is a requirement for designing efficient guided transdifferentiation strategies. In recent years we have seen a diversification of methods for the generation of replacement $\beta$ cells from non- $\beta$-cells (Figure 3), including the up-regulation of $\beta$-cell-specific factors, as well as the modulation of general regulators of cell differentiation and the cell cycle, both in pancreatic and extra-pancreatic tissues. Given the functional complexity of $\beta$-cells, it is unlikely that the artificial modulation of one single factor will suffice to produce a bona-fide $\beta$-cell equivalent; rather, a design involving the combinatorial regulation of key $\beta$-cell factors and the niche influence will be required.

Future studies will help identifying the critical molecular targets and signals, which foster the plasticity leading to the generation of replacement $\beta$-like cells. 


\section{Acknowledgements}

We are most grateful to Luiza Ghila, for carefully reading and editing the manuscript. We also thank Kenichiro Furuyama, Fabrizio Thorel and Daniel Ortega for insightful comments and suggestions.

S. C. is supported by grants from the Research Council of Norway (NFR) and the Novo Nordisk Foundation. P.L.H. is supported by grants from the NIH/NIDDK, the Swiss National Science Foundation, the Juvenile Diabetes Research Foundation and the European Union. We apologize for the papers not cited here because of space or scope limitations. 


\section{Figure Legends}

Figure 1. Synopsis of present-day and tentative approaches to treat diabetes. Today, physicians try to maintain and improve insulin secretion and $\beta$-cell survival / function; in extreme situations, the only solution is transplantation (of isolated islets or total pancreas). The two prospective broad strategies of the regenerative medicine approach are $\beta$-cell replacement and $\beta$-cell regeneration. The two largely rely on the exploitation of the recently discovered cell plasticity of the adult.

Developing an efficient protective immunomodulation against $\beta$-cell autoimmunity will be an additional requirement in T1D conditions.

Figure 2. The natural strategies to replenish lost cell populations in vivo rely upon adaptive increased cell proliferation, in tissues with high renewal rates, or on adaptive changes of cell identity (conversion), in tissues with low proliferation capacity.

At the tissular injury level, limb amputation does not imply the loss of a given specific cell type, since in the remaining member all cell types are present, in contrast with selective cell ablation situations; therefore, limb regeneration after partial amputation appears as "low tissular injury" condition. The examples listed are referenced in Table 1.

Figure 3. Integrative view of the innate and guided cell conversion approaches aimed at reconstituting lost $\beta$-cells, classified according to the cell type of origin and the nature of the reprogramming stimuli.

DT, diphtheria toxin-mediated $\beta$-cell ablation (as used in references \#49 and \#51); PDL, pancreatic duct ligation (surgical method to trigger pancreatitis in rodent models, and therefore study pancreatic tissue remodeling). 


\begin{tabular}{|c|c|c|c|}
\hline Organism & Organ / Tissue & Cell Conversion Type & References \\
\hline $\begin{array}{l}\text { Cnidarians } \\
\text { (Hydra vulgaris } A E P \text { ) }\end{array}$ & $\begin{array}{l}\text { Hypostome } \\
\text { (Granular mucous cells ) }\end{array}$ & Direct & Siebert et al. $2008^{73}$ \\
\hline $\begin{array}{l}\text { Echinoderms } \\
\text { (Eupentacta fraudatrix) }\end{array}$ & $\begin{array}{l}\text { Digestive tract } \\
\text { (anterior rudiment) }\end{array}$ & Direct & Mashanov et al. $2005^{74}$ \\
\hline $\begin{array}{l}\text { Echinoderms } \\
\text { (Holothuria forskali) }\end{array}$ & Cuvierian tubules & Indirect & $\begin{array}{l}\text { VandenSpiegel et al. } \\
2000^{75}\end{array}$ \\
\hline $\begin{array}{l}\text { Echinoderms } \\
\text { (Apostichopus japonicus) }\end{array}$ & Respiratory trees & Direct \& Indirect & $\begin{array}{l}\text { Dolmatov and } \\
\text { Ginanova } 2009^{76}\end{array}$ \\
\hline $\begin{array}{l}\text { Fish (Zebrafish) } \\
\text { (Danio rerio) }\end{array}$ & Liver & Indirect & He et al. $2014^{77}$ \\
\hline $\begin{array}{l}\text { Fish (Zebrafish) } \\
\text { (Danio rerio) }\end{array}$ & Heart & Indirect & Zhang et al. $2013^{78}$ \\
\hline $\begin{array}{l}\text { Teleosts (Zebrafish) } \\
\text { (Danio rerio) }\end{array}$ & $\begin{array}{l}\text { Fin rays } \\
\text { (osteoblasts-depleted fins) }\end{array}$ & Indirect & Singh et al. $2012^{33}$ \\
\hline $\begin{array}{l}\text { Teleosts (Zebrafish) } \\
\text { (Danio rerio) }\end{array}$ & $\begin{array}{l}\text { Lateral line and inner ears } \\
\text { (sensory hair cells) }\end{array}$ & Direct & $\begin{array}{l}\text { Reviewed in: } \\
\text { Monroe et al. } 2015^{79}\end{array}$ \\
\hline $\begin{array}{l}\text { Amphibians: Anures (Frog) } \\
\text { (Xenopus laevis) }\end{array}$ & $\begin{array}{l}\text { Lens regeneration \& } \\
\text { Neural retina regeneration }\end{array}$ & Indirect & Yoshii et al. $2007^{80}$ \\
\hline $\begin{array}{l}\text { Amphibians: Urodeles (Newt) } \\
\text { (Notophthalmus viridescens) } \\
\text { (Triturus viridescens) } \\
\text { (Cynops pyrrhogaster) }\end{array}$ & $\begin{array}{l}\text { Wolffian lens regeneration \& } \\
\text { Neural retina regeneration }\end{array}$ & Indirect & $\begin{array}{l}\text { Reviewed in: } \\
\text { Barbosa-Sabanero, et } \\
\text { al. } 2012^{81} \text {; } \\
\text { Tsonis et al. } 2004^{82}\end{array}$ \\
\hline $\begin{array}{l}\text { Avians (Chick) } \\
\text { (Gallus gallus) }\end{array}$ & $\begin{array}{l}\text { Cochlea } \\
\text { (sensory hair cells) }\end{array}$ & Direct \& Indirect & $\begin{array}{l}\text { Reviewed in: } \\
\text { Stone and Cotanche } \\
2007^{83}\end{array}$ \\
\hline $\begin{array}{l}\text { Mammals (Mouse) } \\
\text { (Mus musculus) } \\
\text { JUVENILES }\end{array}$ & $\begin{array}{l}\text { Pancreas } \\
\text { ( } \beta \text {-cells) }\end{array}$ & Indirect & Chera et al. $2014^{50}$ \\
\hline $\begin{array}{l}\text { Mammals (Mouse) } \\
\text { (Mus musculus) } \\
\text { ADULTS }\end{array}$ & $\begin{array}{l}\text { Pancreas } \\
\text { ( } \beta \text {-cells) }\end{array}$ & Direct & $\begin{array}{l}\text { Thorel, Népote et al. } \\
2010^{48}\end{array}$ \\
\hline $\begin{array}{l}\text { Mammals (Mouse) } \\
\text { (Mus musculus) }\end{array}$ & Skin and heart & Direct & $\begin{array}{l}\text { Davis, Burr et al. } \\
2012^{84} \\
\text { Reviewed in: } \\
\text { Hinz } 2007^{85}\end{array}$ \\
\hline $\begin{array}{l}\text { Mammals (Mouse) } \\
\text { (Mus musculus) }\end{array}$ & $\begin{array}{l}\text { Peripheral nerves } \\
\text { (Wallerian degeneration) }\end{array}$ & Indirect & $\begin{array}{l}\text { Arthur-Farraj et al. } \\
2012^{86} \\
\text { Reviewed in: } \\
\text { Jessen et al. } 2015^{87} \\
\text { Jessen et al. } 2015^{22}\end{array}$ \\
\hline $\begin{array}{l}\text { Mammals (Mouse) } \\
\text { (Mus musculus) } \\
\text { NEONATAL }\end{array}$ & $\begin{array}{l}\text { Cochlea } \\
\text { (sensory hair cells) }\end{array}$ & Direct \& Indirect & $\begin{array}{l}\text { Bramhall et al. } 2014^{88} \\
\text { Cox et al. } 2014^{89} \\
\text { Reviewed in: } \\
\text { Richardson and } \\
\text { Atkinson } 2015^{90}\end{array}$ \\
\hline $\begin{array}{l}\text { Mammals (Mouse) } \\
\text { (Mus musculus) }\end{array}$ & $\begin{array}{l}\text { Liver } \\
\text { (biliary epithelial cells) }\end{array}$ & unknown & Yanger et al. $2013^{91}$ \\
\hline
\end{tabular}

Table 1. Documented examples of regeneration through adaptive cell plasticity in kingdom Animalia. 


\section{References}

1 Gillespie, K. M. Type 1 diabetes: pathogenesis and prevention. CMAJ 175, 165-170, doi:10.1503/cmaj.060244 (2006).

2 Alejandro, E. U., Gregg, B., Blandino-Rosano, M., Cras-Meneur, C. \& BernalMizrachi, E. Natural history of beta-cell adaptation and failure in type 2 diabetes. $\mathrm{Mol}$ Aspects Med 42, 19-41, doi:10.1016/j.mam.2014.12.002 (2015).

*3 Pagliuca, F. W. et al. Generation of functional human pancreatic beta cells in vitro. Cell 159, 428-439, doi:10.1016/j.cell.2014.09.040 (2014).

With an scalable suspension-based culture system, the authors generated glucose-responsive insulin-producing cells using sequential modulation of multiple signaling pathways in a three-dimensional cell culture system, without any genetic modification. These are the first surrogate differentiated glucoseresponsive insulin-producing cells obtained in vitro, which function like adult human $\beta$-cells.

4 Russ, H. A. et al. Controlled induction of human pancreatic progenitors produces functional beta-like cells in vitro. $E M B O \quad J$ 34, 1759-1772, doi:10.15252/embj.201591058 (2015).

5 Desgraz, R., Bonal, C. \& Herrera, P. L. $\beta$-cell regeneration: the pancreatic intrinsic faculty. Trends Endocrinol Metab 22, 34-43, doi:10.1016/j.tem.2010.09.004 (2011).

6 Call, M. K., Grogg, M. W. \& Tsonis, P. A. Eye on regeneration. Anat Rec B New Anat 287, 42-48, doi:10.1002/ar.b.20084 (2005).

7 Bruni, A., Gala-Lopez, B., Pepper, A. R., Abualhassan, N. S. \& Shapiro, A. J. Islet cell transplantation for the treatment of type 1 diabetes: recent advances and future challenges. Diabetes Metab Syndr Obes 7, 211-223, doi:10.2147/dmso.s50789 (2014).

8 Zhao, T., Zhang, Z. N., Rong, Z. \& Xu, Y. Immunogenicity of induced pluripotent stem cells. Nature 474, 212-215, doi:10.1038/nature10135 (2011).

9 Araki, R. et al. Negligible immunogenicity of terminally differentiated cells derived from induced pluripotent or embryonic stem cells. Nature 494, 100-104, doi:10.1038/nature11807 (2013).

*10 Vegas, A. J. et al. Long-term glycemic control using polymer-encapsulated human stem cell-derived beta cells in immune-competent mice. Nat Med, doi:10.1038/nm.4030 (2016).

Using triazole-thiomorpholine dioxide alginate capsules, the authors were able to transplant glucose-responsive mature $\beta$-cells, which were derived from human embryonic stem cells. This is the first study showing glycemic correction in diabetic mice without any immunosuppression.

$* * 11$ Hua, H. et al. iPSC-derived $\beta$ cells model diabetes due to glucokinase deficiency. J Clin Invest 123, 3146-3153, doi:10.1172/JCI67638 (2013).

Using skin biopsies from two MODY2 subjects, the authors generated induced glucose-responsive mature $\beta$-cells and showed that higher glucose levels are needed to stimulate insulin secretion in GCK mutant $\beta$-cells. This is the first study showing mutation-specific phenotype reversion upon gene sequence correction by homologous recombination.

12 Rezania, A. et al. Reversal of diabetes with insulin-producing cells derived in vitro from human pluripotent stem cells. Nat Biotechnol 32, 1121-1133, doi:10.1038/nbt.3033 (2014).

13 Robinton, D. A. \& Daley, G. Q. The promise of induced pluripotent stem cells in research and therapy. Nature 481, 295-305, doi:10.1038/nature10761 (2012).

14 Dor, Y., Brown, J., Martinez, O. I. \& Melton, D. A. Adult pancreatic beta-cells are formed by self-duplication rather than stem-cell differentiation. Nature 429, 41-46, doi:10.1038/nature02520 (2004). 
$15 \mathrm{Li}, \mathrm{W}$. et al. mTORC1 pathway mediates beta cell compensatory proliferation in 60 $\%$ partial-pancreatectomy mice. Endocrine, doi:10.1007/s12020-016-0861-5 (2016).

16 Wang, G. et al. First quantitative high-throughput screen in zebrafish identifies novel pathways for increasing pancreatic beta-cell mass. Elife 4, doi:10.7554/eLife.08261 (2015).

17 Tsonis, P. A. Regeneration via transdifferentiation: the lens and hair cells. Hear Res 227, 28-31, doi:10.1016/j.heares.2006.06.011 (2007).

18 Tsonis, P. A. Regenerative biology: the emerging field of tissue repair and restoration. Differentiation 70, 397-409, doi:10.1046/j.1432-0436.2002.700802.x (2002).

19 Tsonis, P. A. Regeneration in vertebrates. Dev Biol 221, 273-284, doi:10.1006/dbio.2000.9667 (2000).

20 Sisakhtnezhad, S. \& Matin, M. M. Transdifferentiation: a cell and molecular reprogramming process. Cell Tissue Res 348, 379-396, doi:10.1007/s00441-0121403-y (2012).

21 Slack, J. M. Metaplasia and transdifferentiation: from pure biology to the clinic. Nat Rev Mol Cell Biol 8, 369-378, doi:10.1038/nrm2146 (2007).

22 Jessen, K. R., Mirsky, R. \& Arthur-Farraj, P. The Role of Cell Plasticity in Tissue Repair: Adaptive Cellular Reprogramming. Dev Cell 34, 613-620, doi:10.1016/j.devcel.2015.09.005 (2015).

23 Thowfeequ, S., Myatt, E. J. \& Tosh, D. Transdifferentiation in developmental biology, disease, and in therapy. Dev Dyn 236, 3208-3217, doi:10.1002/dvdy.21336 (2007).

24 Poss, K. D. Advances in understanding tissue regenerative capacity and mechanisms in animals. Nat Rev Genet 11, 710-722, doi:10.1038/nrg2879 (2010).

25 Knapp, D. \& Tanaka, E. M. Regeneration and reprogramming. Curr Opin Genet Dev 22, 485-493, doi:10.1016/j.gde.2012.09.006 (2012).

26 Jopling, C., Boue, S. \& Izpisua Belmonte, J. C. Dedifferentiation, transdifferentiation and reprogramming: three routes to regeneration. Nat Rev Mol Cell Biol 12, 79-89, doi:10.1038/nrm3043 (2011).

27 Gemberling, M., Bailey, T. J., Hyde, D. R. \& Poss, K. D. The zebrafish as a model for complex tissue regeneration. Trends Genet 29, 611-620, doi:10.1016/j.tig.2013.07.003 (2013).

$28 \mathrm{Kragl}$, M. et al. Novel insights into the flexibility of cell and positional identity during urodele limb regeneration. Cold Spring Harb Symp Quant Biol 73, 583-592, doi:10.1101/sqb.2008.73.034 (2008).

29 Tu, S. \& Johnson, S. L. Fate restriction in the growing and regenerating zebrafish fin. Dev Cell 20, 725-732, doi:10.1016/j.devcel.2011.04.013 (2011).

30 Knopf, F. et al. Bone regenerates via dedifferentiation of osteoblasts in the zebrafish fin. Dev Cell 20, 713-724, doi:10.1016/j.devcel.2011.04.014 (2011).

31 Sousa, S. et al. Differentiated skeletal cells contribute to blastema formation during zebrafish fin regeneration. Development 138, 3897-3905, doi:10.1242/dev.064717 (2011).

32 Kragl, M. et al. Cells keep a memory of their tissue origin during axolotl limb regeneration. Nature 460, 60-65, doi:10.1038/nature08152 (2009).

33 Singh, S. P., Holdway, J. E. \& Poss, K. D. Regeneration of amputated zebrafish fin rays from de novo osteoblasts. Dev Cell 22, 879-886, doi:10.1016/j.devcel.2012.03.006 (2012).

34 Morgan, T. H. REGENERATION AND LIABILITY TO INJURY. Science 14, 235 248, doi:10.1126/science.14.346.235 (1901).

35 Eguchi, G. \& Kodama, R. Transdifferentiation. Curr Opin Cell Biol 5, 1023-1028 (1993).

36 Herrera, P. L. Defining the cell lineages of the islets of Langerhans using transgenic mice. Int J Dev Biol 46, 97-103 (2002). 
37 Herrera, P. L., Nepote, V. \& Delacour, A. Pancreatic cell lineage analyses in mice. Endocrine 19, 267-278, doi:10.1385/ENDO:19:3:267 (2002).

38 Weissman, T. A. \& Pan, Y. A. Brainbow: new resources and emerging biological applications for multicolor genetic labeling and analysis. Genetics 199, 293-306, doi:10.1534/genetics.114.172510 (2015).

39 Van Keymeulen, A. \& Blanpain, C. Tracing epithelial stem cells during development, homeostasis, and repair. J Cell Biol 197, 575-584, doi:10.1083/jcb.201201041 (2012).

40 Thirumangalathu, S. \& Barlow, L. A. In vivo fate tracing studies of mammalian taste cell progenitors. Ann $N \quad Y$ Acad Sci 1170, 34-38, doi:10.1111/j.17496632.2009.04371.x (2009).

41 Herrera, P. L. Adult insulin- and glucagon-producing cells differentiate from two independent cell lineages. Development 127, 2317-2322 (2000).

42 Suzuki, A. Evidence of cell-fate conversion from hepatocytes to cholangiocytes in the injured liver: in-vivo genetic lineage-tracing approaches. Curr Opin Gastroenterol 31, 247-251, doi:10.1097/mog.0000000000000172 (2015).

43 Romagnani, P., Rinkevich, Y. \& Dekel, B. The use of lineage tracing to study kidney injury and regeneration. Nat Rev Nephrol 11, 420-431, doi:10.1038/nrneph.2015.67 (2015).

44 Joseph, C. et al. Deciphering hematopoietic stem cells in their niches: a critical appraisal of genetic models, lineage tracing, and imaging strategies. Cell Stem Cell 13, 520-533, doi:10.1016/j.stem.2013.10.010 (2013).

**45 Desgraz, R. \& Herrera, P. L. Pancreatic neurogenin 3-expressing cells are unipotent islet precursors. Development 136, 3567-3574, doi:10.1242/dev.039214 (2009).

Using MADM, a genetic system in which a Cre-dependent chromosomal translocation labels rare cells, at extremely low mosaic efficiency, the authors performed in vivo clonal analyses in mice to study the proliferation and differentiation of very large numbers of single $\operatorname{Ngn3}(+)$. This study shows that at the single cell level, Ngn3(+) cells are not pluripotent, but unipotent islet precursors.

46 Clevers, H. The intestinal crypt, a prototype stem cell compartment. Cell 154, $274-$ 284, doi:10.1016/j.cell.2013.07.004 (2013).

47 Blanpain, C. \& Simons, B. D. Unravelling stem cell dynamics by lineage tracing. Nat Rev Mol Cell Biol 14, 489-502, doi:10.1038/nrm3625 (2013).

**48 Thorel, F. et al. Conversion of adult pancreatic alpha-cells to beta-cells after extreme beta-cell loss. Nature 464, 1149-1154, doi:10.1038/nature08894 (2010).

Using a genetic model of $\beta$-cell ablation (RIP-DTR), the authors showed that the murine pancreas has a innate ability to regenerate new insulin-producing cells. This is the first study to show intra-islet plasticity and direct transdifferentiation of one endocrine cell into another type of endocrine cell.

49 Al-Hasani, K. et al. Adult duct-lining cells can reprogram into beta-like cells able to counter repeated cycles of toxin-induced diabetes. Dev Cell 26, 86-100, doi:10.1016/j.devcel.2013.05.018 (2013).

**50 Chera, S. et al. Diabetes recovery by age-dependent conversion of pancreatic delta-cells into insulin producers. Nature 514, 503-507, doi:10.1038/nature13633 (2014).

Total ablation of $\beta$-cells in prepubertal mice induces dedifferentiation of somatostating-producing cells and their redifferentiation into insulin-producing cells. This is the first study showing spontaneous diabetes recovery after total $\beta$ cell ablation.

51 Spijker, H. S. et al. Loss of $\beta$-Cell Identity Occurs in Type 2 Diabetes and Is Associated With Islet Amyloid Deposits. Diabetes 64, 2928-2938, doi:10.2337/db141752 (2015). 
52 Chung, C. H., Hao, E., Piran, R., Keinan, E. \& Levine, F. Pancreatic beta-cell neogenesis by direct conversion from mature alpha-cells. Stem Cells 28, 1630-1638, doi:10.1002/stem.482 (2010).

**53 Zhou, Q., Brown, J., Kanarek, A., Rajagopal, J. \& Melton, D. A. In vivo reprogramming of adult pancreatic exocrine cells to beta-cells. Nature 455, 627632, doi:10.1038/nature07314 (2008).

Using adenoviruses encoding 3 transcription factors (Ngn3, Pdx1, Mafa), the authors were able to reprogram differentiated pancreatic exocrine cells into $\beta$ like cells in adult mice.

$54 \mathrm{Li}, \mathrm{W}$. et al. Long-term persistence and development of induced pancreatic beta cells generated by lineage conversion of acinar cells. Nat Biotechnol 32, 1223-1230, doi:10.1038/nbt.3082 (2014).

55 Heller, R. S. et al. Improved glucose tolerance and acinar dysmorphogenesis by targeted expression of transcription factor PDX-1 to the exocrine pancreas. Diabetes 50, 1553-1561 (2001).

**56 Baeyens, L. et al. Transient cytokine treatment induces acinar cell reprogramming and regenerates functional beta cell mass in diabetic mice. Nat Biotechnol 32, 76-83, doi:10.1038/nbt.2747 (2014).

Using transient cytokine exposure, the authors were able to promote acinar-to- $\beta$ cell reprogramming via Stat3 signaling.

**57 Collombat, P. et al. The ectopic expression of Pax4 in the mouse pancreas converts progenitor cells into alpha and subsequently beta cells. Cell 138, 449462, doi:10.1016/j.cell.2009.05.035 (2009).

Using using different cell-type specific promoters, the authors showed that Pax4 forces endocrine precursor cells to adopt a $\beta$-cell fate.

58 Ben-Othman, N. et al. From pancreatic islet formation to beta-cell regeneration. Diabetes Res Clin Pract 101, 1-9, doi:10.1016/j.diabres.2013.01.013 (2013).

59 Thorel, F. et al. Normal glucagon signaling and $\beta$-cell function after near-total $\alpha$-cell ablation in adult mice. Diabetes 60, 2872-2882, doi:10.2337/db11-0876 (2011).

60 Rodriguez-Seguel, E. et al. Mutually exclusive signaling signatures define the hepatic and pancreatic progenitor cell lineage divergence. Genes Dev 27, 1932-1946, doi:10.1101/gad.220244.113 (2013).

61 Zaret, K. S. \& Grompe, M. Generation and regeneration of cells of the liver and pancreas. Science 322, 1490-1494, doi:10.1126/science.1161431 (2008).

62 Chen, Y. J. et al. De novo formation of insulin-producing "neo-beta cell islets" from intestinal crypts. Cell Rep 6, 1046-1058, doi:10.1016/j.celrep.2014.02.013 (2014).

**63 Banga, A., Akinci, E., Greder, L. V., Dutton, J. R. \& Slack, J. M. In vivo reprogramming of Sox9+ cells in the liver to insulin-secreting ducts. Proc Natl Acad Sci U S A 109, 15336-15341, doi:10.1073/pnas.1201701109 (2012).

Using adenoviral polycistronic constructs (Ngn3, Pdx1, Mafa), the authors were able to reprogram liver cells into insulin-producing cells. This study shows that insulin ${ }^{+}$cells do not arise from hepatocytes, but from a $\mathrm{SOX}^{+}$population, likely from small bile ducts or peri-biliary glands.

**64 Talchai, C., Xuan, S., Kitamura, T., DePinho, R. A. \& Accili, D. Generation of functional insulin-producing cells in the gut by Foxo1 ablation. Nat Genet 44, 406-412, S401, doi:10.1038/ng.2215 (2012).

Upon FoxO1 inactivation in gut epithelium, the authors showed that the Neurog3(+) enteroendocrine progenitor cells give rise to gut insulin-producingg cells, which expressed markers of mature $\beta$ cells and secreted insulin in response to glucose and sulfonylureas.

**65 Talchai, C., Xuan, S., Lin, H. V., Sussel, L. \& Accili, D. Pancreatic beta cell dedifferentiation as a mechanism of diabetic beta cell failure. Cell 150, 12231234, doi:10.1016/j.cell.2012.07.029 (2012).

Under conditions of physiological stress, adult murine $\beta$-cells lacking FoxO1 acquire a progenitor-like state that permits their conversion to other pancreatic 
endocrine cell types. This is the first study showing the role of FoxO1 in $\beta$-cell homeostasis.

66 Herrera, P. L. et al. Ablation of islet endocrine cells by targeted expression of hormone-promoter-driven toxigenes. Proc Natl Acad Sci U S A 91, 12999-13003 (1994).

67 Karges, B. et al. Complete long-term recovery of beta-cell function in autoimmune type 1 diabetes after insulin treatment. Diabetes Care 27, 1207-1208 (2004).

68 Karges, B. et al. Immunological mechanisms associated with long-term remission of human type 1 diabetes. Diabetes Metab Res Rev 22, 184-189, doi:10.1002/dmrr.600 (2006).

69 Yoneda, S. et al. Predominance of beta-cell neogenesis rather than replication in humans with an impaired glucose tolerance and newly diagnosed diabetes. $J$ Clin Endocrinol Metab 98, 2053-2061, doi:10.1210/jc.2012-3832 (2013).

70 White, M. G. et al. Expression of mesenchymal and alpha-cell phenotypic markers in islet beta-cells in recently diagnosed diabetes. Diabetes Care 36, 3818-3820, doi:10.2337/dc13-0705 (2013).

71 Butler, A. E. et al. Marked expansion of exocrine and endocrine pancreas with incretin therapy in humans with increased exocrine pancreas dysplasia and the potential for glucagon-producing neuroendocrine tumors. Diabetes 62, 2595-2604, doi:10.2337/db12-1686 (2013).

72 Bramswig, N. C. et al. Epigenomic plasticity enables human pancreatic alpha to beta cell reprogramming. J Clin Invest 123, 1275-1284, doi:10.1172/jci66514 (2013).

73 Siebert, S., Anton-Erxleben, F. \& Bosch, T. C. Cell type complexity in the basal metazoan Hydra is maintained by both stem cell based mechanisms and transdifferentiation. Dev Biol 313, 13-24, doi:10.1016/j.ydbio.2007.09.007 (2008).

74 Mashanov, V. S., Dolmatov, I. Y. \& Heinzeller, T. Transdifferentiation in holothurian gut regeneration. Biol Bull 209, 184-193 (2005).

75 VandenSpiegel, D., Jangoux, M. \& Flammang, P. Maintaining the line of defense: regeneration of Cuvierian tubules in the sea cucumber Holothuria forskali (Echinodermata, Holothuroidea). Biol Bull 198, 34-49 (2000).

76 Dolmatov, I. Y. \& Ginanova, T. T. Post-autotomy regeneration of respiratory trees in the holothurian Apostichopus japonicus (Holothuroidea, Aspidochirotida). Cell Tissue Res 336, 41-58, doi:10.1007/s00441-009-0761-6 (2009).

77 He, J., Lu, H., Zou, Q. \& Luo, L. Regeneration of liver after extreme hepatocyte loss occurs mainly via biliary transdifferentiation in zebrafish. Gastroenterology 146, 789-800.e788, doi:10.1053/j.gastro.2013.11.045 (2014).

78 Zhang, R. et al. In vivo cardiac reprogramming contributes to zebrafish heart regeneration. Nature 498, 497-501, doi:10.1038/nature12322 (2013).

79 Monroe, J. D., Rajadinakaran, G. \& Smith, M. E. Sensory hair cell death and regeneration in fishes. Front Cell Neurosci 9, 131, doi:10.3389/fncel.2015.00131 (2015).

80 Yoshii, C., Ueda, Y., Okamoto, M. \& Araki, M. Neural retinal regeneration in the anuran amphibian Xenopus laevis post-metamorphosis: transdifferentiation of retinal pigmented epithelium regenerates the neural retina. Dev Biol 303, 45-56, doi:10.1016/j.ydbio.2006.11.024 (2007).

81 Barbosa-Sabanero, K. et al. Lens and retina regeneration: new perspectives from model organisms. Biochem J 447, 321-334, doi:10.1042/BJ20120813 (2012).

82 Tsonis, P. A., Madhavan, M., Tancous, E. E. \& Del Rio-Tsonis, K. A newt's eye view of lens regeneration. Int J Dev Biol 48, 975-980, doi:10.1387/ijdb.041867pt (2004).

83 Stone, J. S. \& Cotanche, D. A. Hair cell regeneration in the avian auditory epithelium. Int J Dev Biol 51, 633-647, doi:10.1387/ijdb.072408js (2007).

84 Davis, J., Burr, A. R., Davis, G. F., Birnbaumer, L. \& Molkentin, J. D. A TRPC6dependent pathway for myofibroblast transdifferentiation and wound healing in vivo. Dev Cell 23, 705-715, doi:10.1016/j.devcel.2012.08.017 (2012). 
85 Hinz, B. Formation and function of the myofibroblast during tissue repair. $J$ Invest Dermatol 127, 526-537, doi:10.1038/sj.jid.5700613 (2007).

86 Arthur-Farraj, P. J. et al. c-Jun reprograms Schwann cells of injured nerves to generate a repair cell essential for regeneration. Neuron 75, 633-647, doi:10.1016/j.neuron.2012.06.021 (2012).

87 Jessen, K. R., Mirsky, R. \& Lloyd, A. C. Schwann Cells: Development and Role in Nerve Repair. Cold Spring Harb Perspect Biol 7, a020487, doi:10.1101/cshperspect.a020487 (2015).

88 Bramhall, N. F., Shi, F., Arnold, K., Hochedlinger, K. \& Edge, A. S. Lgr5-positive supporting cells generate new hair cells in the postnatal cochlea. Stem Cell Reports 2 , 311-322, doi:10.1016/j.stemcr.2014.01.008 (2014).

89 Cox, B. C. et al. Spontaneous hair cell regeneration in the neonatal mouse cochlea in vivo. Development 141, 816-829, doi:10.1242/dev.103036 (2014).

90 Richardson, R. T. \& Atkinson, P. J. Atoh1 gene therapy in the cochlea for hair cell regeneration. Expert Opin Biol Ther 15, 417-430, doi:10.1517/14712598.2015.1009889 (2015).

91 Yanger, K. et al. Robust cellular reprogramming occurs spontaneously during liver regeneration. Genes Dev 27, 719-724, doi:10.1101/gad.207803.112 (2013). 


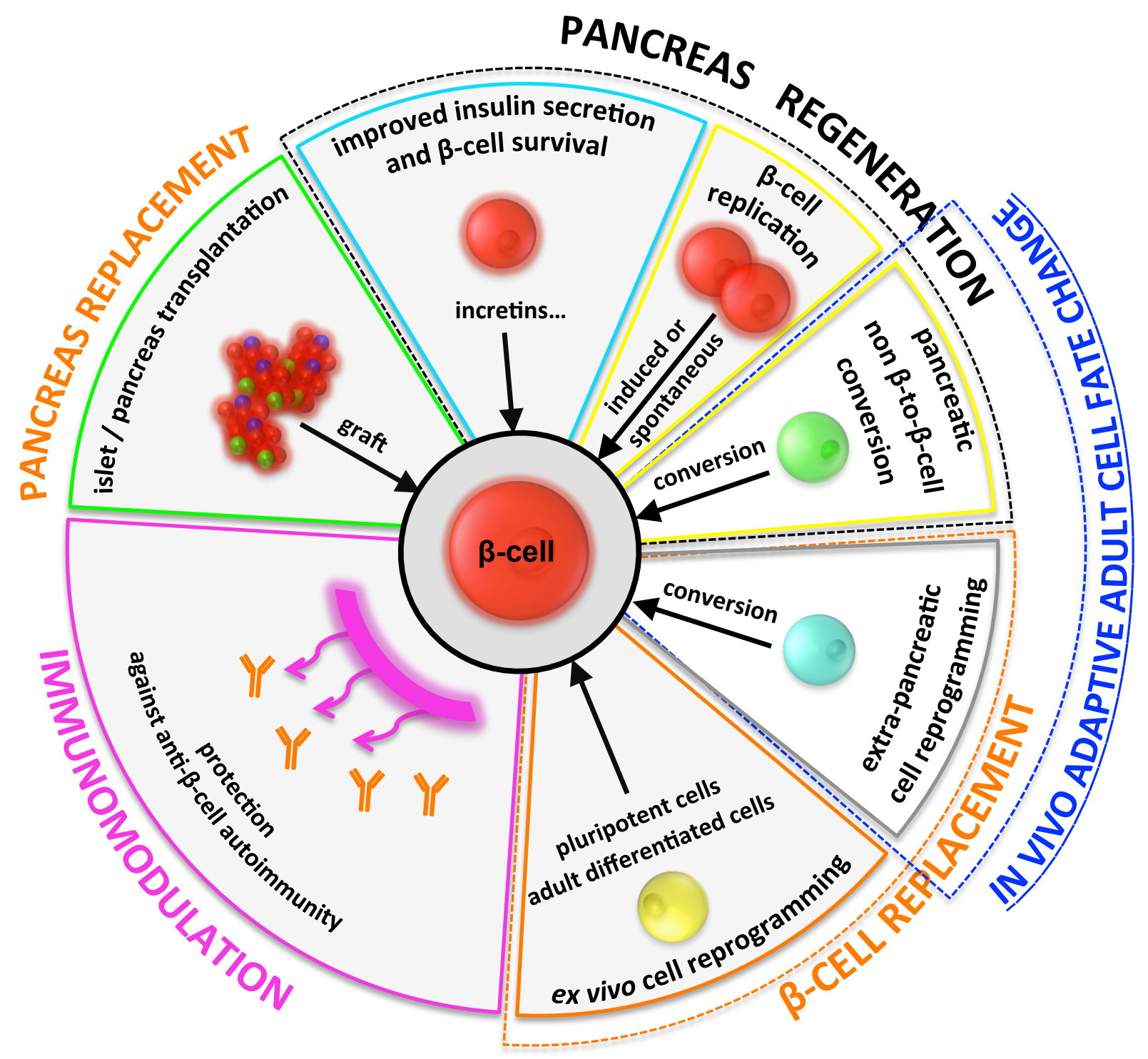

Figure 1

Chera \& Herrera 
Adaptive Cellular

Proliferation

Adaptive Cellular

PROLIFERATION

adult progenitor cells or

surviving differentiated cells

skeletal muscle

mammalian liver

amphibian \& fish

limb regeneration (fate restriction)

partial beta-cell loss

LOW TISSULAR INJURY EXTENT

TRANSIENT

REPROGRAMING

(indirect effect - wound healing)

murine skin, heart

Schwann cells in peripheral nerves HIGH Change of Identity

INDIRECT CONVERSION de-differentiation \& proliferation

amphibian lens \& neural retina fish heart, liver, fin avian \& murine cochlea echinoderm cuvierian tubules murine islet delta-to-beta (juvenile)

DIRECT CONVERSION transient hybrid phenotype

cnidarian hypostome

echinoderm digestive tract echinoderm respiratory tree

fish lateral line, inner ear avian \& murine cochlea

murine islet alpha-to-beta (adult)

LOW

Figure 2

Chera \& Herrera 


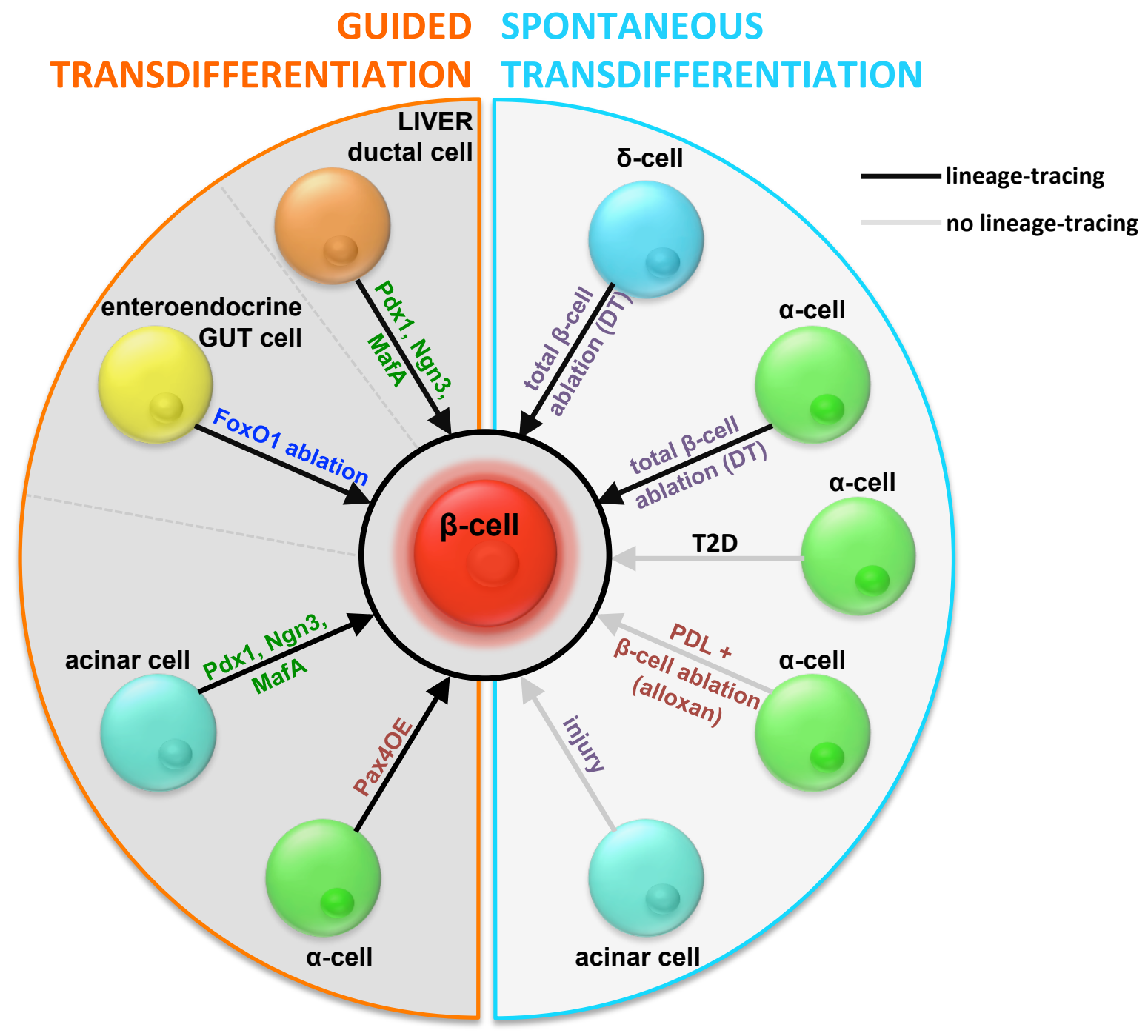

Figure 3

Chera \& Herrera 